ISSN 0103-5150

Fisioter. Mov., Curitiba, v. 30, n. 2, p. 219-226, Apr./June 2017

Licenciado sob uma Licença Creative Commons

DOI: http://dx.doi.org/10.1590/1980-5918.030.002.A002

(c)

\title{
Posterior chain flexibility and lower back pain in farm workers
}

\author{
Flexibilidade da cadeia posterior e dor \\ lombar em trabalhadores rurais
}

\author{
Marcia Regina da Silva ${ }^{[a, b]}$, Lucimare Ferraz ${ }^{[a, c]}$, Fátima Ferretti ${ }^{[a, c]}$, Cristiane Sfredo $^{[a]^{*}}$ \\ [a] Universidade Comunitária da Região de Chapecó (Unochapecó), Chapecó, SC, Brazil \\ [b] Centro Universitário Metodista (IPA), Porto Alegre, RS, Brazil \\ [c] Universidade Federal de São Paulo (UNIFESP), São Paulo, SP, Brazil
}

\section{Abstract}

Introduction: Flexibility is an essential component of physical aptitude that reduces the incidence of muscle distention and improves movement efficiency and posture. Objective: To analyze posterior chain flexibility and lower back pain (LBP) in farm workers from a city in western Santa Catarina state, Brazil. Methods: Quantitative and cross-sectional study conducted with 185 rural workers, average age of 44.24 ( \pm 10.83$)$ years. The Rural Worker Health Questionnaire, containing individual issues related to work; sit and reach box, goniometer, visual analog scale (VAS) and Oswestry and Roland-Morris questionnaires were used to evaluate posterior chain flexibility, hamstring muscle length, pain and lumbar spine dysfunction, respectively. Flexibility was compared with the degree of dysfunction using one-way ANOVA followed by the Bonferroni post hoc test. Results: 181 (97.8\%) workers reported LBP symptoms: $100 \%$ of the women and $95.2 \%$ of the men. The average Oswestry score was $7.09( \pm 8.25)$, Roland-Morris $1.22( \pm 1.63)$, and VAS $5.81( \pm 2.5)$. Average flexibility by the sit and reach test (SRT) was $23.91 \mathrm{~cm}( \pm 18.81)$; straight leg raise (SLR), $66^{\circ}( \pm 11.77)$ and popliteal angle $123.21^{\circ}( \pm 12.45)$. There was a significant difference in the popliteal angle $(p=0.003)$ and SLR (0.001) when compared with the degree of dysfunction. Women showed significant differences in all tests; however, the post hoc test showed a significant difference only in the SRT ( $p=0.013)$, and women with minimal dysfunction had

MRS: MS, e-mail: marciaf@unochapeco.edu.br

LF: PhD, e-mail: lferraz@unochapeco.edu.br

FF: PhD, e-mail: ferrettifisio@yahoo.com.br

CF: undergrad, e-mail: cris.uno@unochapeco.edu.br 
greater flexibility in relation to those with severe dysfunction. Conclusion: Self-reported LBP was severe and women with higher levels of dysfunction exhibited less posterior chain flexibility.

Keywords: Articular Range of Motion. Low Back Pain. Rural Population.

\section{Resumo}

Introdução: A flexibilidade é um componente essencial da aptidão física que reduz a incidência de distensão muscular e melhora a eficiência do movimento e postura. Objetivo: Analisar a flexibilidade da cadeia muscular posterior e dor lombar (DL) em trabalhadores rurais de um município do Extremo Oeste Catarinense. Métodos: Pesquisa quantitativa e de corte transversal com 185 trabalhadores rurais, idade média de 44,24 ( $\pm 10,83)$ anos. Utilizou-se questionário contendo questões relacionadas ao trabalho; Banco de Wells, goniômetro, escala visual analógica da dor (EVA), questionário Oswestry e Rolland-Morris para avaliação da flexibilidade da cadeia posterior, comprimento muscular de isquiotibiais, dor e disfunção da coluna lombar, respectivamente. A flexibilidade foi comparada com o grau de disfunção por Anova One-Way seguida do teste post hoc de Bonferroni. Resultados: 181 (97,8\%) trabalhadores relataram algum sintoma de DL: 100\% das mulheres e 95,2\% dos homens. Média do escore Oswestry: 7,09 ( $\pm 8,25)$; Roland-Morris, 1,22 ( $\pm 1,63) ; E V A, 5,81( \pm 2,5)$. Flexibilidade média pelo Banco de Wells (FBW): $23,91 \mathrm{~cm}( \pm 18,81)$; teste de elevação da perna retificada $(T E P R), 66^{\circ}( \pm 11,77)$ e ângulo poplíteo $123,21^{\circ}$ $( \pm 12,45)$. Houve diferença significativa no ângulo poplíteo $(p=0,003)$ e TEPR $(0,001)$ quando comparados com o grau de disfunção. As mulheres apresentaram diferença significativa em todos os testes realizados, no entanto, no teste post hoc, houve diferença significativa apenas na FBW ( $p=0,013)$, sendo que mulheres com grau de disfunção mínima apresentaram maior flexibilidade em relação às com disfunção severa. Conclusão: $A$ DL autorreferida foi alta e as mulheres com maior grau de disfunção apresentam menor flexibilidade da cadeia posterior.

Palavras-chave: Amplitude de Movimento Articular. Dor Lombar. População Rural.

\section{Introduction}

Flexibility is considered the absolute range of movement of a segment and is an essential component of physical aptitude that improves movement efficiency, reduces the incidence of muscle distention and enhances posture (1). It is also related to the extensibility of musculotendinous units that cross a joint, based on their ability to deform and relax to the movement (2).

Muscle strength and flexibility are frequently related to lower back pain, especially when there is ischiotibial or iliotibial band retraction or abdominal and erector spinae muscle weakness. Moreover, physiological changes that occur in the musculoskeletal system during the aging process reduce torso muscle flexibility and strength, in addition to changing posture and the nutrition of intervertebral discs, cartilage, bones and ligaments, which may predispose individuals to a higher incidence of pain (1).

Back pain affects 60 to $80 \%$ of individuals at some time in their life, but is more frequent between the ages of 25 and 60 years (average 40 years), with a greater incidence in women (1). Lower back pain is common in women, primarily in the postmenopausal period, due to the changes that occur in this phase, higher fat concentration and lower lean mass (3).

Among the subjects with the greatest risk for lower back pain and musculoskeletal disorders are rural workers, since their daily activities involve physical effort and exhausting postures, where lifting and transport of heavy loads, prolonged and repeated bending of the spine, and repetitive movements are risk factors for sustaining injury $(4,5)$.

Barrero et al. (6) estimated the prevalence of self-reported lower back pain and assessed the association between physical exposure and lower back pain in a rural Chinese population of 13,965 men and women aged between 25 and 64 years. The authors found a high prevalence of lower back pain in the last year (64\%), more prevalent in women of all age groups. Moreover, working under moderate or heavy 
physical stress and previous or current exposure to vibration were positively associated with lower back and other related musculoskeletal pain.

A systematic review of 41 studies on currentestimates of lower back pain and risk factors associated with its emergence suggests that the incidence is similar in community and professional environments, irrespective of its definition. The risk factors related to primary or transitory lower back pain were physical and psychosocial (7).

Brazil has regions with predominantly agricultural activities and in the western portion of Santa Catarina state specifically, there is a prevalence of family farming, due to the presence of agro-industries. In this respect, there are no specific studies on flexibility and lower back pain in rural workers, and the results of those on similar topics are contradictory. Ferreira etal. (8) found that the prevalence of back pain in 972 adults aged between 20 and 69 years, residing in the city of Pelotas, Rio Grande do Sul state, was $63.1 \%$. The lower back region was the most cited (40\%), and women and self-perception of poor health were the variables associated with back pain.

Mangini and Pivetta (9) demonstrated that ischiotibial muscle shortening is present in $80 \%$ of the 20 patients with lower back pain complaints. However, Taechasubamorn et al. (10) report that there is no relationship between flexibility and lower back pain, while other studies found that flexibility interferes negatively in some aspects, or causes greater risk for chronic lower back pain $(11,12)$. Studies that tested intervention protocols demonstrated that improved flexibility is one of the factors related to decreased lower back pain symptoms $(13,14)$.

Considering the aforementioned aspects, the present study aimed to analyze posterior chain muscle flexibility and lower back pain in rural workers of an agricultural community in western Santa Catarina state, as well as characterize the types of physical activity, determine the degree of dysfunction and related disorders and compare posterior chain and ischiotibial flexibility with the degree of dysfunction in workers in general and by sex.

\section{Methods}

This is a quantitative-observational study with a cross-sectional design, conducted in the municipality of Caxambu do Sul, with a population of 4559 inhabitants, whose demographic characteristic is predominantly rural. The target population was composed of rural workers of both sexes, aged between 18 and 59 years, who were actively employed in 2014 . The sample was estimated at 338 workers, based on the number of individuals in the intended age range enrolled in DATASUS (15) in the base year 2012, with a 95\% confidence level and 5\% sampling error.

Excluded from the study were workers outside the stipulated age range, those who did not work in agriculture, who were not located at home in three attempts or who declined to participate in the study. The final sample was composed of 185 rural workers.

Data collection involved application of the Faria rural worker health questionnaire (16), specifically the section with questions regarding the sociodemographic and occupational status of the workers. Next, two other instruments related to lower back pain were applied: The Oswestry Disability Index (ODI), which evaluates the presence of low back pain and the Roland Morris questionnaire, which assesses physical disabilities, in addition to the visual analog scale for pain.

The ODI is composed of 10 sections that describe pain or limitations resulting from lumbago. Each section has six items that describe an increasing degree of severity, zero indicating little or no pain or functional limitation and five extreme pain and/or limitation. The total score is obtained by adding the number of points from each section, with a maximum score of 50 . The percent of pain and/or limitation is obtained by multiplying the score by 2 , which represents the maximum pain level perceived by the patient. Based on this score, the degree of dysfunction is classified as minimal (from zero to 20 points), moderate (from 21 to 40 points) or severe (more than 41 points) (17).

The Roland Morris questionnaire is a simple, fast and easy-to-calculate measure of self-reported physical disability for patients with back pain. It contains 24 items scored zero (no) or one (yes), with the total ranging from zero (suggesting no disability) and 24 (severe disability) (18-20).

The visual analog scale (VAS) is a simple assessment consisting of a graduated scale on a $10 \mathrm{~cm}$-long horizontal line with faces depicting different expressions that correspond to a score from zero, or no pain, to ten, representing unbearable pain.

The flexibility test was then applied to the posterior chain and ischiotibial muscles.

Posterior chain flexibility was obtained by anterior flexion of the torso on a Sanny sit and reach box ${ }^{\circledR}$. From a sitting position over the ischia, with knees completely extended, ankles dorsiflexed and soles of the 
feet resting on the box, subjects bend their torso up to the limit of its range of motion, sliding their toes along the ruler of the sit and reach box. The total distance reached represents the total flexibility achieved. The mean of three attempts is considered (21-23).

Ischiotibial flexibility was obtained by applying the muscle length tests using a Carci goniometer ${ }^{\circledR}$, measuring the popliteal angle, and the straight leg raise test.

The popliteal angle was measured with the subject in the horizontal dorsal decubitus position, the hip of the lower limb to be tested flexed at $90^{\circ}$, the contralateral limb in complete extension on the floor or examination table, without bending the knee and hip. Next, the knee of the limb to be tested was actively extended, with the ankle and foot relaxed, up to the maximum point in which the subject did not compensate with the spine or contralateral limb (24). The measure was taken three times to obtain the final average. According to Porter (25), the measure is considered normal when it is between $165^{\circ}$ and $180^{\circ}$ of range of motion (ROM).

The straight leg raise test was conducted with the subject in dorsal decubitus, lower limbs extended and lumbar spine and sacrum against the table. Maintaining the initial position, the participants flexed their hip with the knee extended to the maximum (leg raise), with no compensations. An angle of approximately $80^{\circ}$ between the tables and flexed hip was considered normal range of ischiotibial length (26).

Data analysis was conducted using the SPSS 20.0 program, starting with descriptive statistical analysis of the variables under study. Next the homogeneity test of quantitative variances was applied using the Levene test. Mean ischiotibial flexibility and posterior chain values were compared in the three groups, based on the degree of dysfunction obtained on the ODI, for all the workers, using one-way analysis of variance (One-way ANOVA), followed by the Bonferroni post hoc test. The same test was used separately to compare the groups composed of men and women. Statistical significance was considered for $\mathrm{p}<0.05$.

The study was approved by the Unochapecó Human Being Research Ethics Committee, under protocol 156/14, in compliance with Resolution 466/12 of the National Health Council.

\section{Results}

Of the 185 rural workers assessed, 84 (45.4\%) were men and 101 (54.6\%) were women; 172 (93\%) were of Italian descent, and $162(87.6 \%)$ were married. The mean number of years of schooling was 7.41 ( \pm 3.15$)$, ranging between 1 and 16 years, and the mean time they lived in a rural environment was $28.77( \pm 14.5)$ years.

With respect to tasks performed on the property, working in the garden $(51.4 \%)$ was reported more by women (93.1\%), while working in the fields (30.8\%) was more common in men $(66.7 \%)$. Only $2.7 \%$ of the subjects took care of animals, showing that the predominant activity was agriculture, given that the remaining tasks reported were related to the maintenance and repair of farm machinery.

In regard to lower back pain, nearly all the farm workers (97.8\%) reported some low back pain, 100\% of the women and $95.2 \%$ of the men. A total of $48.6 \%$ exhibited disability, according to the Roland Morris questionnaire; however, it was minimal, with scores ranging between 1 and 8 points on a scale of 24 .

Table 1 shows the means and standard deviations of flexibility and self-reported lower back pain of rural workers on the ODI, Roland Morris and Visual Analog Scale (VAS), as well as the degree of dysfunction, as classified by the Oswestry Disability Index.

A comparison between both ischiotibial and posterior chain flexibility and the degree of dysfunction showed a statistically significant difference in the popliteal angle and the straight leg raise test $(\mathrm{p}=$ 0.003 and 0.001 respectively). (Table 2)

However, the post hoc test revealed a statistically significant change between workers who reported a minimal degree of dysfunction and those with a moderate level ( $p=0.015)$, that is, the former exhibit greater flexibility, albeit lower than expected.

With respect to the straight leg raise test, which also assesses ischiotibial muscles, the workers who reported a minimal degree of dysfunction differed from those with a moderate or severe level $(\mathrm{p}=0.023$ and 0.016 , respectively), the last two groups exhibiting less flexibility than workers with mild dysfunction.

A comparison between flexibility and the degree of dysfunction in male and female workers showed a statistically significant difference in women in all the tests (Table 3). However, a comparison of degree of dysfunction in the post hoc test showed a statistically significant difference between female workers with minimal dysfunction and those with a severe level ( $p=0.013$ ), only in sit and reach flexibility. 
Table 1 - Means and standard deviations of flexibility tests, lower back pain reported by rural workers, and degree of lumbar dysfunction

\begin{tabular}{lccc}
\hline Variables & $\begin{array}{c}\text { Total } \\
(\mathbf{n}=\mathbf{1 8 5}) \\
\mathbf{M}( \pm \mathbf{S D})\end{array}$ & $\begin{array}{c}\text { Male } \\
(\mathbf{n}=\mathbf{8 4}) \\
\mathbf{M}( \pm \mathbf{S D})\end{array}$ & $\begin{array}{c}\text { Female } \\
(\mathbf{n}=\mathbf{1 0 1}) \\
\mathbf{M}( \pm \mathbf{S D})\end{array}$ \\
\hline Popliteal angle $\left(^{\circ}\right)$ & $123.21(12.45)$ & $124.08(11.87)$ & $122.48(12.93)$ \\
SLRT $\left(^{\circ}\right)$ & $66.00(11.77)$ & $66.67(12.13)$ & $65.45(11.49)$ \\
SRT $(\mathrm{cm})$ & $23.91(18.81)$ & $25.52(27.70)$ & $22.58(3.18)$ \\
Oswestry & $7.09(8.25)$ & $6.18(7.83)$ & $7.84(8.54)$ \\
Roland Morris & $1.22(1.63)$ & $1.13(1.58)$ & $1.30(1.67)$ \\
VAS & $5.81(2.50)$ & $5.57(2.49)$ & $6.01(2.50)$ \\
\hline Owestry Degree of & Total & Male & Female \\
dysfunction & $\mathbf{( n = 1 8 5 )}$ & $\mathbf{( n = 8 4 )}$ & $\mathbf{n}=101)$ \\
& $\mathbf{M}( \pm \mathbf{S D})$ & $\mathbf{M}( \pm$ SD) & $77(76.2)$ \\
\hline Minimal & $145(78.4)$ & $68(81)$ & $15(14.9)$ \\
Moderate & $28(15.1)$ & $13(15.5)$ & $9(8.9)$ \\
Severe & $12(6.5)$ & $3(3.6)$ & \\
\hline
\end{tabular}

Note: M: mean; SD: Standard deviation; SLRT: straight leg raise test; SRT: sit and reach test; VAS: Visual analog test for pain.

Table 2 - Mean ischiotibial and posterior chain flexibility according to the degree of flexibility of workers (one-way ANOVA)

\begin{tabular}{lccccc}
\hline $\begin{array}{l}\text { Degree of } \\
\text { dysfunction }\end{array}$ & $\begin{array}{c}\text { Minimal } \\
(\mathbf{n}=\mathbf{1 4 5}) \\
\mathbf{M}( \pm \mathbf{S D})\end{array}$ & $\begin{array}{c}\text { Moderate } \\
(\mathbf{n}=\mathbf{2 8}) \\
\mathbf{M}( \pm \mathbf{S D})\end{array}$ & $\begin{array}{c}\text { Severe } \\
(\mathbf{n}=\mathbf{1 2}) \\
\mathbf{M}( \pm \mathbf{S D})\end{array}$ & $\boldsymbol{p}$ & Levene \\
Variable & & & & & \\
\hline Popliteal angle $\left(^{\circ}\right)$ & $124.81(12.79)$ & $117.68(10.04)$ & $116.67(6.85)$ & $0.003^{*}$ & 0.270 \\
SLRT $\left({ }^{\circ}\right)$ & $67.59(11.67)$ & $61.25(9.96)$ & $57.92(11.37)$ & $0.001^{*}$ & 0.521 \\
SRT $(\mathrm{cm})$ & $24.71(21.15)$ & $21.47(2.81)$ & $19.97(2.18)$ & 0.536 & 0.728 \\
\hline
\end{tabular}

Note: M: mean; SD: Standard deviation; SLRT: Straight leg raise test; SRT: Sit and reach test; $p$ : significance level. * $p<0.05$; Levene: Homogeneity of variance test.

Table 3 - Assessment of posterior chain flexibility according to the degree of dysfunction in men and women workers (oneway ANOVA

\begin{tabular}{lcccccc}
\hline Gender & $\begin{array}{c}\text { Degree of } \\
\text { dysfunction/ } \\
\text { Variable }\end{array}$ & $\begin{array}{c}\text { Minimal } \\
(\mathbf{n}=\mathbf{1 4 5}) \\
\mathbf{M}( \pm \mathbf{S D})\end{array}$ & $\begin{array}{c}\text { Moderate } \\
(\mathbf{n}=\mathbf{2 8}) \\
\mathbf{M}( \pm \mathbf{S D})\end{array}$ & $\begin{array}{c}\text { Severe } \\
(\mathbf{n}=\mathbf{1 2}) \\
\mathbf{M}( \pm \mathbf{S D})\end{array}$ & $\boldsymbol{p}$ & Levene \\
\hline Female & Popliteal angle $\left(^{\circ}\right)$ & $124.35(13.39)$ & $116.33(11.09)$ & $116.67(5.59)$ & $0.031^{*}$ & 0.245 \\
$(\mathrm{n}=101)$ & $\mathrm{SLRT}\left({ }^{\circ}\right)$ & $67.08(11.57)$ & $61.33(10.60)$ & $58.33(8.29)$ & $0.030^{*}$ & 0.423 \\
& $\mathrm{SRT}(\mathrm{cm})$ & $23.13(3.07)$ & $21.31(3.22)$ & $20.01(2.23)$ & $0.004^{*}$ & 0.465 \\
\hline Male & Popliteal angle $\left({ }^{\circ}\right)$ & $125.34(12.16)$ & $119.23(8.86)$ & $116.67(11.55)$ & 0.128 & 0.654 \\
$(\mathrm{n}=84)$ & $\mathrm{SLRT}\left({ }^{\circ}\right)$ & $68.16(11.84)$ & $61.15(9.61)$ & $56.67(20.82)$ & 0.054 & 0.208 \\
& $\mathrm{SRT}(\mathrm{cm})$ & $26.51(30.73)$ & $21.67(2.35)$ & $19.87(2.50)$ & 0.798 & 0.731 \\
\hline
\end{tabular}

Note: M: mean; SD: Standard deviation; SLRT: Straight leg raise test; SRT: Sit and reach test; $p$ : significance level. ${ }^{\star} p<0.05$; Levene: Homogeneity of variance test. 


\section{Discussion}

It was observed that both men and women reported moderate pain on the VAS, with a mean of 5.81 $( \pm 2.50)$. The frequency of self-reported lower back pain was high $(97.8 \%)$, with only 4 workers $(2.2 \%)$ reporting no pain.

Cho et al. (27) determined the prevalence of low back pain in 4,181 residents of a rural community in South Korea aged between 40 and 79 years, and found an accumulated prevalence of lower back pain of $61.3 \%$, and higher in women.

Melo Filho et al. (28) revealed that the percent of lower back pain in 108 individuals (17 men and 91 women) between 18 and 30 years of age was $20 \%$, $18.68 \%$ in the women and $29.41 \%$ in men. The mean Roland-Morris score was 3.77 and mean pain score 3.32 , that is, a low impact on functionality and selfreported pain in the lumbar spine.

Mascarenhas and Santos (29) assessed pain and functional capacity in 17 individuals with chronic lumbago in Jequié, Bahia state. The authors found that $70.6 \%$ of subjects reported intense pain and, according to the Roland-Morris questionnaire, $23.5 \%$ were classified as having functional disability. Another study with 117 patients with chronic back pain from three health facilities in São Paulo state, found a 65\% disability prevalence, $80.7 \%$ being moderate to severe (30).

Stefane et al. (31) assessed perceived pain, disability and quality of life in 97 individuals with chronic lower back pain. The study applied the RolandMorris questionnaire, visual analog scale for pain and Whoqol Bref for quality of life. Mean disability was 14.4, pain intensity at the time of the interview 5.4, and quality of life 48.1 points. The physical quality of life domain was the most compromised, with 44.1 points. A strong association was observed between disability and the physical quality of life domain, indicating that disability has a negative impact on the quality of life of these individuals suffering from chronic lower back pain.

The results of self-reported pain in the present study are higher than those obtained by the aforementioned authors $(6,27-31)$. The Roland Morris disability findings were lower than those of other studies $(28,30,31)$. With respect to pain assessment, the mean results were similar to those reported by Stefane et al. (31) and higher than those of Melo Filho et al. (28). Although the present study did not assess or associate quality of life, this variable could be investigated in the rural working population.

The type, duration and overload of work may interfere in the self-report and occurrence of pain. Meucci et al. (32) assessed the prevalence of work limitations caused by lower back pain in agricultural workers employed in tobacco farming and concluded that the tasks they were forced to abandon with the greatest frequency are those that make greater demands on the musculoskeletal system, such as carrying leaves, transplanting seedlings, stacking firewood and harvesting bottom leaves. In this respect, studies that relate the type of function to pain in different cultures and countries are needed, in order to organize prevention programs according to each situation.

Although rural workers perform different tasks in their daily routine and are characterized as active individuals, these activities often involve bent-over or prolonged sitting postures, or demand intense physical effort without adequate muscle flexibility, especially in the posterior chain, which may predispose individuals to retractions, resulting in pain.

In a study by Taechasubamorn et al (10), mean ischiotibial flexibility, obtained by the straight leg raise test, was $90.36^{\circ}( \pm 10.41)$ for a group of rice growers with chronic lower back pain and $89.15^{\circ}$ $( \pm 8.17)$ in healthy farm workers, while lumbar muscle flexibility was $16.93 \mathrm{~cm}( \pm 6.19)$ and $15.52 \mathrm{~cm}$ $( \pm 6.92)$, respectively. The present study obtained different results from the abovementioned investigation, whereby ischiotibial flexibility on the straight leg raise test was lower $\left(66^{\circ} \pm 11.77\right)$ and lumbar muscle flexibility on the sit and reach test higher $(23.91 \pm 18.81 \mathrm{~cm})$. Although these parameters show no statistically significant difference in the study by Taechasubamorn et al. (10), the present investigation found a significant difference for ischiotibial flexibility, where higher degrees of dysfunction are related to lower mean flexibility levels, especially in women.

Another study revealed that patients with low back pain have less ischiotibial flexibility, due to greater muscle stiffness. Furthermore, the decreased tolerance to stretching is related to real mechanical restriction and not self-reported behavior measures of pain, such as the Oswestry disability index, visual analog scale, overall health status and well-being (33).

More studies are needed on the relationship between flexibility and lower back pain, and the measures adopted to assess this pain should be more objective and monitored in the short, mid and long 
term, in order to determine whether there is an association with spinal problems and other musculoskeletal disorders.

The fact that the findings of this study in terms of pain intensity differed from the scores reported on the pain/dysfunction index and disability questionnaires raises questions regarding how rural workers deal with pain in their daily tasks and whether they are resistant to it, since there is normally no one to assume or share the physical demands of their daily activities, and they may feel that pain does not prevent them from performing certain tasks.

\section{Conclusion}

Most of the rural workers in this study were women, married, of Italian descent, residing for more than 20 years in a rural environment, and predominantly involved in agricultural activities. The percent of selfreported lower back pain was high (97.8\%), and there was a significant change between flexibility and degree of dysfunction, predominantly in women, with lower flexibility levels related to a higher degree of dysfunction.

More studies are needed with the rural population to investigate parameters other than flexibility, such as torso, abdominal and lower limb muscle strength, in addition to quantifying physical activities so that the results obtained can help in providing adequate preventive and therapeutic measures for this population.

\section{References}

1. Hamill J, Knutzen KM. Bases biomecânicas do movimento humano. 3rd ed. São Paulo: Manole; 2012. 532 p. Portuguese.

2. Kisner C, Colby LA. Exercícios terapêuticos: fundamentos e técnicas. 5th ed. São Paulo: Manole; 2009. 972 p. Portuguese.

3. Maraschin R, Vieira PS, Leguisamo CP, Dal'Vesco F, Santi JP. Dor lombar crônica e dor nos membros inferiores em idosas: etiologia em revisão. Fisioter mov. 2010;23(4):627-39.

4. Fathallah FA. Musculoskeletal disorders in laborintensive agriculture. Appl Ergon. 2010;41(6):738-43.
5. Alves RA, Guimarães MC. De Que Sofrem os Trabalhadores Rurais? - Análise dos Principais Motivos de Acidentes e Adoecimentos nas Atividades Rurais. Informe GEPEC. 2012;16(2):39-56.

6. Barrero LH, Hsu YH, Terwedow H, Perry MJ, Dennerlein JT, Brain JD, et al. Prevalence and physical determinants of low back pain in a rural Chinese population. Spine. 2006;31(23):2728-34.

7. Taylor JB, Goode AP, George SZ, Cook CE. Incidence and risk factors for first-time incident low back pain: a systematic review and meta-analysis. Spine J. 2104;14(10): 2299-319.

8. Ferreira GD, Silva MC, Rombaldi AJ, Wrege ED, Siqueira FV, Hallal PC. Prevalência de dor nas costas e fatores associados em adultos do Sul do Brasil: estudo de base populacional. Rev Bras Fisioter. 2011;15(1):31-6.

9. Mangini E, Pivetta HMF. Prevalência de encurtamento dos músculos isquiotibiais em pacientes com queixas de dor lombar. Ter Man. 2009;7(34):432-8.

10. Taechasubamorn P, Nopkesorn T, Pannarunothai S. Comparison of physical fitness between rice farmers with and without chronic low back pain: a cross-sectional study. J Med Assoc Thai. 2010;93(12):1415-21.

11. Sandler RD, Sui X, Church TS, Fritz SL, Beattie PF, Blair $\mathrm{SN}$. Are flexibility and muscle-strengthening activities associated with a higher risk of developing low back pain? J Sci Med Sport. 2014;17(4):361-5.

12. Polito MD, Maranhão Neto GA, Lira VA. Componentes da aptidão física e sua influência sobre a prevalência de lombalgia. Rev bras Ciênc Mov. 2003;11(2):35-40.

13. Puppin MAFL, Marques AP, Silva AG, Neto HDAF. Alongamento muscular na dor lombar crônica inespecífica: uma estratégia do método GDS. Fisioter Pesq. 2011;18(2): 116-21.

14. Kofotolis N, Kellis E. Effects of two 4-week proprioceptive neuromuscular facilitation programs on muscle endurance, flexibility, and functional performance in women with chronic low back pain. Phys Ther. 2006;86(7):1001-12.

15. Datasus. Departamento de Informática do SUS - DATASUS. Secretaria Executiva do Ministério da Saúde [cited 2014 Jul 16]. Available from: http://www.datasus.gov.br. 
16. Faria NMX. A saúde do trabalhador rural [dissertation]. Pelotas: Universidade Federal de Pelotas; 2005. Portuguese.

17. Masseli MR, Lopes MM, Serillo TB. Índice funcional de Oswestry de pacientes submetidos à cirurgia para descompressão de raízes nervosas. Rev. Fisioter. Univ. São Paulo. 2003;10(2):70-6.

18. Sardá Jr JJ, Nicholas MK, Pimenta CAM, Asghari A, Thieme AL. Validação do questionário de incapacidade Roland Morris para dor em geral. Rev Dor. 2010;11(1):28-36.

19. Costa LOP, Maher CG, Latimer J, Ferreira PH, Pozzi GC, Ribeiro RN. Psychometric characteristics of the brazilian-portuguese versions of the functional rating index and the roland morris disability questionnaire. Spine. 2007;32(17):1902-7.

20. Nusbaum L, Natour J, Ferraz MB, Goldenberg J. Translation, adaptation and validation of the Roland-Morris questionnaire-Brazil Roland-Morris. Braz J Med Biol Res. 2001;34(2):203-10.

21. Gaya A, Silva G. Projeto esporte Brasil: manual de aplicação de medidas e testes, normas e critérios de avaliação. Porto Alegre (Brazil): PROESP-BR; 2009.

22. Bertolla F, Baroni BM, Leal Jr EC, Oltramari JD. Efeito de um programa de treinamento utilizando o método Pilates ${ }^{\circledR}$ na flexibilidade de atletas juvenis de futsal. Rev Bras Med Esporte. 2007;13(4):222-6.

23. Araujo SS, Oliveira H, Paz AA, Santos CAS. Avaliação da flexibilidade de adolescentes através do teste sentar e alcançar. Rev Digit Vida Saude. 2002;1(1):1-5.

24. Affonso Filho AA, Navarro RD. Avaliação do ângulo poplíteo em joelhos de adolescentes assintomáticos. Rev Bras Ortop. 2002;37(10):461-6.

25. Porter S. Fisioterapia de Tidy. 13th ed. Rio de Janeiro: Elsevier; 2005.

26. Kendall FP, McCreary EK, Provance PG. Músculos, provas e funções: com postura e dor. 4th ed. São Paulo: Manole; 1995. Portuguese.

27. Cho NH, Jung YO, Lim SH, Chung CK, Kim HA. The prevalence and risk factors of low back pain in rural community residents of Korea. Spine (Phila Pa 1976). 2012;37(24):2001-10.
28. Melo Filho J, Santos Menossi, BR, Preis C, Neto LB, Neto AS. Análise da musculatura estabilizadora lombopélvica em jovens com e sem dor lombar. Fisioter Mov. 2013;26(3):587-94.

29. Mascarenhas CHM, Santos LS. Avaliação da dor e da capacidade funcional em indivíduos com lombalgia crônica. Rev Inst Cienc Saude. 2011;29(3):205-8.

30. Salvetti MG, Mattos Pimenta CA, Braga PE, Corrêa CF. Incapacidade relacionada à dor lombar crônica: prevalência e fatores associados. Rev Esc Enferm USP. 2012;46(spe):16-23.

31. Stefane T, Santos AM, Marinovic A, Hortense P. Dor lombar crônica: intensidade de dor, incapacidade e qualidade de vida. Acta paul Enferm. 2013;26(1):14-20.

32. Meucci RD, Fassa AG, Faria NMX, Fiori NS, Miranda VI, Resende D. Limitação no trabalho por dor lombar em fumicultores do sul do Brasil. Rev Bras Saude Ocup. 2014;39(129):6-16.

33. Marshall PW, Mannion J, Murphy BA. Extensibility of the hamstrings is best explained by mechanical components of muscle contraction, not behavioral measures in individuals with chronic low back pain. PM\&R, 2009;1(8):709-18

Received in 06/02/2015 Recebido em 02/06/2015

Approved in 06/07/2016 Aprovado em 07/06/2016 